\title{
PENGARUH FAKTOR DEMOGRAFI TERHADAP LITERASI KEUANGAN
}

\section{THE EFFECT OF DEMOGRAPHIC FACTORS ON FINANCIAL LITERATION}

\author{
${ }^{1}$ Raja Ria Yusnita, ${ }^{2}$ Muhammad Abdi. \\ ${ }^{1,2}$ Universitas Islam Riau \\ raja_ria10@yahoo.com ${ }^{1,}$ abdi_ak@yahoo.com ${ }^{2}$
}

\begin{abstract}
Financial knowledge is one of the important aspects in life today. This study aims to determine the level of financial literacy in motorbike workshop SMEs in Kec.Siak Hulu Kab. Kampar and analyze whether demographic factors consisting of education level, income level, duration of business and age affect the level of financial literacy among workshop entrepreneurs. The number of samples in this study are 50 workshop entrepreneurs with the research method used is the survey method by obtaining data through questionnaires. While the analysis used in this test is binary logistic regression analysis. The results showed that the level of financial literacy for business people was in the low category with a percentage of 48\%. The variables that influence the level of financial literacy are income level variables and besides these variables which consist of education level, duration of business and age does not affect the level of financial literacy for business actors.
\end{abstract}

Keywords: Financial Literacy, Education Level, Income Level, Duration, Age

\begin{tabular}{|c|c|}
\hline \multicolumn{2}{|l|}{$\begin{array}{r}\text { akunci: Lit } \\
\text { Us }\end{array}$} \\
\hline $\begin{array}{l}\text { PENDAHULUAN } \\
\text { Pada era modern ini pelaku- } \\
\text { pelaku UMKM sudah banyak } \\
\text { bermunculan, mereka merupakan } \\
\text { golongan manusia kretif yang } \\
\text { menyalurkan bakat mereka untuk di } \\
\text { kembangkan dan mencoba untuk }\end{array}$ & $\begin{array}{l}\text { mengupayakan usaha mereka agar } \\
\text { tetap dapat berdiri dan bertahan dalam } \\
\text { menghadapi banyak persaingan. Dalam } \\
\text { hal ini pengetahuan akan pengelolaan } \\
\text { keuanganpun juga sangat di perlukan } \\
\text { terutama untuk para pelaku- } \\
\text { pelakuUMKM tersebut, agar mereka }\end{array}$ \\
\hline
\end{tabular}


dapat mengelola dan memanfaatkan aset yang mereka miliki.

Dalam beberapa tahun belakangan ini isu mengenai literasi keuangan (financial literacy) tengah hangat diperbincangkan, perhatian khusus terhadap literasi keuangan diakibatkan oleh keinginan sebuah negara untuk memiliki penduduk yang berkualitas dan memiliki kecerdasan finansial yang baik, Pengetahuan finansial merupakan salah satu aspek penting dalam kehidupan saat ini. Kecerdasan finansial adalah Pengetahuan dalam mengelola aset pribadi (Widayati, 2012). Individu harus memiliki suatu pengetahuan dan keterampilan untuk mengelola sumber keuangan pribadinya secara efektif demi kesejahteraannya dan juga demi kelansungan usahanya, kepandaian dalam mengelola keuangan dalam dunia usaha sangat di butuhkan agar keseimbangan financial dapat terlaksana dengan baik.

Literasi keuangan dapat dikatakan sebagai kemampuan seseorang untuk mendapatkan, memahami, dan mengevaluasi informasi yang relevan untuk pengambilan keputusan dengan memahami konsekuensi finansial yang ditimbulkannya (Krishna, 2010). Melihat kondisi perekonomian saat ini, peran literasi keuangan menjadi lebih penting, individu membutuhkan pengetahuan keuangan dasar serta skill untuk mengelola sumber daya keuangan secara efektif demi kesejahteraan hidupnya, terutama bagi seorang wirausaha yang sering melakukan aktivitas pengambilan keputusan terutama yang berhubungan dengan keuangan usahanya, yang mana pengusaha haruslah memiliki kesadaran akan penting nya suatu literasi keuangan demi meningkatkan keberhasilan usahanya.
Ada beberapa faktor yang mempengaruhi tingkat literasi keuangan seseorang individu, salah satu diantara nya adalah latar belakang seorang individu itu sendiriatau bisa diistilahkan dengan faktor demografinya.Yang dimaksud dari faktor demografi ini adalahmerupakan gambaran mengenai latar belakang seseorang sehingga dapat mempengaruhi financial literacy mereka (Mandel, 2008).

Dalam penelitian yang dilakukan oleh Rita dan Kusumawati (2010) menyatakan bahwa faktor demografi terdiri dari gender, usia, tingkat pendidikan, status perkawinan, pekerjaan, jabatan, dan pendapatan. Usia adalah batasan atau tingkat ukuran hidup yang mempengaruhi kondisi fisik seseorang. Dari beberapa faktor tesebut maka dapat di simpulkan kaitannya dengan literasi keuangan adalah akan sangat disayangkan sekali jika seandainya seorang tersebut memiliki tingkat pendapatan yang tinggi namun tidak bisa mengelola modal yang dia miliki dengan baik karena pemahaman akan financial nya yang kurang dan sangat di sayangkan juga jika seandainya seorang pengusaha tersebut sudah lama berusaha namun perkembangan usahanya hanya sebatas disitu saja karena tidak memiliki kemampuan akan mengelola modal yang dia miliki untuk berinvestasi dan aksis pada produk perbankan.

Berdasarkan dari beberapa penelitian terdahulu dapat dilihat bagaimana pengaruh Faktor Demografi terhadap Literasi Keuangan yaitu penelitian yang dilakukan Risky Amaliyah dan Rini Setyo Witiastuti (2015) tentang "Analisis faktor yang mempengaruhi tingkat literasi keuangan di kalangan pelaku usaha keil dan menengah (UMKM) kota 
Tegal", menemukan bahwa tingkat literasi keuangan para pelaku UMKM kota Tegal masih rendah, dengan faktor yang mempengaruhi literasi keuangan terdiri dari gender,tingkat pendidikan dan tingkat pendapatan pelaku usaha.

Berdasarkan penelitian yang dilakukan oleh Tulio Japelli (2009) mengenai financialliteracy, Indonesia ternyata menempati posisi ke-43 di antara 55 negara lainnya.Sementara itu, yang meduduki posisi pertama ialah Singapura diikuti oleh Finlandia, Irlandia, Hongkong, dan Australia. Dan berdasarkan penelitian terakhir yang dilakukan oleh MasterCard (2013), indeks literasi keuangan Indonesia masih rendah dan Indonesia masih menduduki peringkat ke-14 dan tertinggal jauh dengan Malaysia yang menduduki peringkat ke-6. Indonesia sendiri melakukan penelitian untuk mengetahui tingkat literasi keuangan di kalangan masyarakatnya melalui OJK.

Selaras dengan hasil penelitian tersebut, survei yang dilakukan oleh Otoritas Jasa Keuangan pada awal tahun 2014 menunjukan bahwa hanya sebesar $21,84 \%$ penduduk Indonesia yang memahami akan literasi keuangan, sedangkan untuk kelompok usaha mikro kecil dan menengah (UMKM), tingkat literasi keuangan hanya sebesar $15,68 \%$. Dari informasi di atas dapat diketahui bahwa tingkat financial literacy masyarakat Indonesia masih rendah.

Dari penelitian yang dilakukan oleh OJK tersebut maka terdapatlah suatu permasalahan yang harus kita pahami yaitu adalah tingkat literasi keuangan masyarakat indonesia masih sangat lemah dan kemampuan pemahaman dan pengelolaan keuangan masyarakat Indonesia masih sangatlah rendah terutama bagi pelaku UMKM. Dan sangatlah perlu dilakukan pembinaan terhadap pelaku UMKM tentang kesadaran akan pentingnya mengelola keuangan dengan benar yaitu kesadaran ini adalah kesadaran dengan sepenuhnya kesadaran atas dasar suatu pemahaman, kesadaran akan memahami pemamfaatan aset yang dimiliki dan menjauhi pengeluaran pribadi yang tidak berguna dan mengakibatkan terjadinya suatu pemborosan (sumiyati, 2006).

Di dalam penelitian ini peneliti akan meneliti tentang tingkat literasi keuangan pada pelaku UMKM bengkel sepeda motor yang berada di Kec. Siak Hulu Kab. Kampar, yang mana kondisi dari tingkat literasi keuangan pada pelaku UMKM perbengkelan sepeda motor Kec. Siak Hulu saat ini masih di asumsikan kedalam kategori yang rendah, hal ini didasarkan dari survey lapangan awal yang di lakukan oleh peneliti sebelum meneliti lebih lanjut pada penelitian ini, yaitu dengan cara menanyakan beberapa pertanyaan kepada pemilik usaha perbengkelan sepeda motor di Kec. Siak Hulu yang sebanyak 20 bengkel yang mewakili untuk tahap awal dalam penelitian ini.

Yang mana dari 20 perbengkelan hanya 11 perbengkelan yang membuat anggaran pada usahanya, dan hanya 8 perbengkelan yang mencatat pengeluaran harian dan juga, hanya 8 perbengkelan yang menabung secara periodik dan menyediakan dana untuk pengeluaran tidak terduga. Maka berdasarkan dari suvey tersebut peneliti menyimpulkan bahwa tingkat literasi keuangan untuk semua perbengkelan sepeda motor di luar dari survey yang berada di Kec. Siak Hulu masih rendah, dan perlu dilakukan penelitian lebih lanjut mengenai tingkat literasi pada pelaku UMKM bengkel sepeda motor di kec. Siak Hulu ini. Selain untuk mencari bagaimana hasil dari tingkat literasi 
keuangan pada pengusaha UMKM perbengkelan sepeda motor juga untuk menganalisis apa saja faktor demografi yang mempengaruhinya dan untuk memberikan pemahaman kesadaran akan adanya financial kepada pelaku usahanya.

Pemahaman akan literasi keuangan sangat diperlukan bagi para pelaku usaha khususnya bagi pemilik Usaha Mikro Kecil dan Menengah. UMKM penting untuk dijadikan sasaran keterbukaan akses kedalam lembaga keuangan atau biasa disebut dengan financial inklusif, karena UMKM merupakan salah satu ujung tombak perekonomian negara yang mampu menciptakan lapangan kerja baru dan memberikan daya serap sumber daya manusia lebih tinggi lagi, sehingga dapat mengurangi jumlah pengangguran serta tindak kriminalitas.

Netti tinaprilla dan Elang ilik martawijaya (2008), dalam bukunya yang berjudul Punya bisnis sendiri itu nikmat mengistilahkan bahwa dalam mengembangkan aset ada tiga istilah bagi seorang pengusaha,dan pada arus yang ketiga nya adalah Arus Uang Orang Kaya Yang Semakin Kaya yaitu orang yang memamfaatkan
penghasilan mereka dengan mendeposit dan juga denganmembeli saham dan lain-lain, dan mereka berusaha juga untuk menekan pengeluaran dan utang mereka, dengan demikian mereka memiliki saving yang akan melindungi keuangan usahnya dan setelah itu mereka berupaya lagi untuk membeli aset yang memberikan passive income yang lebih besar lagi bagi mereka sehingga setiap aset yang dimiliki terus memberikan penghasilan buat mereka.

Begitulah pentingnya sutau kecerdasan financial bagi seorang pengusaha agar mereka dapat mengelola keuangan mereka sehingga modal yang mereka punya dapat memberikan nilai timbal balik terhadap mereka. Maka dari pemaparan yang di kemukan oleh Netti tinaprilla dan Elang ilik martawijaya tersebut dapat dilihat bahwa pengusaha yang memiilki tingkat keterampilan dalam mengelola keuangan yang tinggi dan kemampuan literasi keuangan yang baikdapat meningkatkan pendapatan usaha.

\begin{tabular}{lll} 
Tabel $\mathbf{1}$ Jumlah UMKM Kab.Kampar Per Desember $\mathbf{2 0 1 6}$ \\
\hline No & Kecamatan & Jumlah \\
\hline 1 & Bangkinang Kota & 2.430 \\
\hline 2 & Bangkinang & 2.848 \\
\hline 3 & Solo & 1.528 \\
\hline 4 & Kuok & 2.173 \\
\hline 5 & Kampar & 2.562 \\
\hline 6 & Kampar Timur & 2.737 \\
\hline 7 & Kampar Utara & 2.531 \\
\hline 8 & Rumbio Jaya & 2.292 \\
\hline 9 & Tapung & 3.344 \\
\hline 10 & Tapung Hilir & 3.892 \\
\hline 11 & Tapung Hulu & 2.794 \\
\hline 12 & Kampar Kiri & 2.914 \\
\hline 13 & Kampar Kiri Tengah & 2.822 \\
\hline 14 & Kampar Kiri Hilir & 2.423 \\
\hline 15 & Kampar Kiri Hulu & 2.137 \\
\hline 16 & Gunung Sahilan & 1.458 \\
\hline 17 & Perhentian Raja & 2.276 \\
\hline 18 & Siak Hulu & 3.899 \\
\hline 19 & Tambang & 2.891 \\
\hline 20 & XIII Koto Kampar & 1.645 \\
\hline 21 & Koto Kampar Hulu & 1.711 \\
\hline Total & & $\mathbf{5 3 . 3 0 7}$ \\
\hline Sumbr & Dinas Koperasi Dan & \\
\hline
\end{tabular}

Sumber : Dinas Koperasi Dan UKM Kabupaten Kampar (2018) 
Berdasarkan tabeldiatas dapat dilihat bahwa dari 21 Kecamatan yang ada di Kabupaten Kampar menunjukkan bahwa Kecamatan Siak Hulu yang merupakan kecmatan dari objek penelitian ini memiliki paling banyak jumlah UMKM yaitu sebesar 3.899 unit usaha, dan Kecamatan Gunung Salihan memiliki paling sedikit jumlah UMKM yaitu sebesar 1.458 unit usaha.

Di kecamatan Siak Hulu merupakan kecamatan yang berbatasan dengan kota
Pekanbaru yang mungkin menjadi salah satu faktor kenapa kecamatan ini memiliki UMKM jenis Biro Dan Jasa yang terbanyak.Dan UMKM jenis bengkel sepeda motor merupakan UMKM yang terbanyak di sektor biro dan jasa pada Kecamatan Siak Hulu, karena hampir semua desa pada kecamatan ini memiliki UMKM bengkel sepeda motor, perkembangan UMKM jenis bengkel sepeda motor di kecamatan siak hulu dapat dilihat di tabel 1.2 yaitu :

Tabel 2. Jumlah UMKM Bengkel Sepeda Motor Di Kec. Siak Hulu

\begin{tabular}{lll}
\hline No & Nama Desa & Jumlah \\
\hline 1 & Buluh Cina & 3 \\
\hline 2 & Buluh Nipis & 6 \\
\hline 3 & Desa Baru & 12 \\
\hline 4 & Kapau Jaya & 4 \\
\hline 5 & Kubang Jaya & 34 \\
\hline 6 & Lubuk Siam & 2 \\
\hline 7 & Pandau Jaya & 29 \\
\hline 8 & Pangkalan Baru & 3 \\
\hline 9 & Pangkalan Serik & 2 \\
\hline 10 & Tanah Merah & 8 \\
\hline 11 & Tanjung Balam & 0 \\
\hline 12 & Teratak Buluh & 7 \\
\hline Total & & $\mathbf{1 1 0}$ \\
\hline
\end{tabular}

Sumber : Survey Lapangan(2018)

Dari data survey lapangan diatas dapat disimpulkan bahwa dari total jumlah UMKM bengkel sepeda motor di Kecamatan Siak Hulu yaitu sebanyak 110 unit usaha bengkel sepeda motor, dapat dilihat desa yang paling banyak UMKM bengkel sepeda motor nya adalah Desa Kubang Jaya yaitu sebanyak 34 unit usaha bengkel sepeda motor dan yang paling sedikit adalah Desa Tanjung Balam yaitu 0 unit usaha atau tidak memiliki UMKM bengkel sepeda motor.

Berkembang pesatnya UMKM di berbagai sektor akan kurang sempurna jika pelaku-pelaku UMKM tersebut masih kurang dalam bijaksana dalam mengelola keuangan mereka mulai dari perencanaan sampai keputusan apa yang akan mereka ambil nanti nya, Terutama untuk pelaku UMKM di bidang perbengkelan sepeda motor masih banyak diantara mereka yang belum bisa mengelola keuangan mereka dengan baik, dan pemahaman-pemahaman akan literasi keuangan untuk mereka dalam menjalankan sebuah usaha sangatlah di perlukan.

Tidaklah hanya kemampuan akan bekerja namun kemampuan akan mengoptimalkan subuah pendapatan dan mengelolanya dengan efektif dan efisien juga merupakan salah faktor yeng mempengaruhi keberhasilan dan keberlansungan akan sebuah usaha. Namun kendala akan hal-hal pemahaman tentang literasi keuanganlah yang saat ini masih kurang dikalangan UMKM di berbagai sektor apapun yang terutama sektor perbengkelan sepeda motor.

Maka dapat disimpulkan bahwa sangatlah perlu dilakukan penelitian lebih lanjut untuk permasalahan pemahaman literasi keuangan oleh pelaku-pelaku UMKM Perbengkelan sepeda motor di Kec. Siak Hulu Kab Kampar ini, karena dengan adanya 
penelitian ini dapat bertujuan untuk menyadarkan para pelaku UMKM perbengkelan Sepeda Motor di Kec. Siak Hulu agar bisa meningkatkan pemahaman dan keterampilan mereka dalam pengelolaan aset dan pendapatan yang mereka miliki dan juga menyadarkan mereka agar berusaha untuk terampil dalam menggunakan instrument keuangan dan produk-produk yang ditawarkan oleh perbankan yang bertujuan untuk meningkatkan kelansungan dan keberhasilan usaha mereka.

Tingkat literasi keuangan yang dimiliki setiap individu tentunya berbeda-beda. Hal tersebut disebabkan oleh perbedaan faktor yang mempengaruhinya sehingga terjadi perbedaan yang signifikan antara individu satu dengan individu lainnya. Miranda Gultom (2005) mengemukakan, beberapa tahun belakangan ini, sistem keuangan internasional semakin berkembang luas. Hal ini tampak pada semakinbanyaknya variasi instrumen keuangan yang beredar di dalam sistem keuangan.Perkembangan instrumen keuangan ini sejalan dengan perkembangan dari lembaga-lembaga keuangan itu sendiri.

\section{a) Perilaku Keuangan (Financial Behavior) \\ Financial Behavior berhubungan} dengan tanggung jawab keuangan seseorang terkait dengan cara pengelolaan keuangan. Tanggung jawab keuangan merupakan proses pengelolaan uang dan aset yang dilakukan secara produktif. Aktivitas utama dalam pengelolaan uang adalah proses penganggaran. Anggaran bertujuan untuk memastikan bahwa individu mampu mengelola kewajiban keuangan secara tepat waktu dengan menggunakan penghasilan yang diterima dalam periode yang sama (Ida dan Dwinta, 2010 dalam penelitian Vincentius Andrew dan Nanik Linawati).

Menurut Hilgert, Holgart dan Baverly (2003), menyebutkan bahwa perilaku keuangan seseorang akan tampak dari seberapa bagus seseorang mengelola uang kas, mengelola utang, tabungan dan pengeluaran-pengeluaran lainnya. Mengelola uang kas seperti bagaimana ketepatan mengelola uang sesuai atau tidak dengan anggaran yang dibuat, dan masih banyak lain-lainnya.

b) Faktor Demografi

Demografi merupakan gambaran mengenai latar belakang seseorang sehingga dapat mempengaruhi financial literacy mereka (Mandel, 2008). Rita dan Kusumawati (2010) menyatakan faktor demografi terdiri dari gender, usia, tingkat pendidikan, status perkawinan, pekerjaan, jabatan, dan pendapatan. Sedangkan Chintia Nur Fitriani Ichwan mengemukakan bahwa faktor demografi terdiri dari gender, pendidikan, usia dan lama berusaha. Usia adalah batasan atau tingkat ukuran hidup yang mempengaruhi kondisi fisik seseorang.

Dalam hal ini dikatakan bahwa perempuan dan etnis minoritas memiliki pengetahuan keuangan yang rendah. Hal tersebut disebabkan oleh tinggi rendahnya pendidikan yang ditempuh, akan tetapi selain pendidikan formal, kemampuan kognitif memiliki peran untuk meningkatkan pengetahuan keuangan. Jadi pada intinya, faktorfaktor yang terdapat dalam demografi yaitu meliputi tingkat pendidikan, dan tingkat pendapatan dan lama berusaha (Tasya Desiyana, 2015).

Pendidikan. Studi Cole et al (2008) mengemukakan bahwa tingkat pendidikan yang ada di masyarakat mempengaruhi tingkat pemahaman, semakain tinggi tingkat pemahaman maka akan semakin tinggi pula tingkat pemahamannya terhadap keuangan. Variabel pendidikan sebagai human 
capital merupakan salah satu variabel yang diharapkan akan memberikan efek terhadap kesejahteraan seseorang. Variabel pendidikan berpengaruh pada produktifitas dan efisiensi kerja seseorang yang kemudian akan mempengaruhi real income individu atau rumah tangga (Rahmatia, 2004).

Pendapatan. Pendapatan (Revenue) yaitu jumlah yang diperoleh setelah memberikan barang atau jasa kepada pelanggan. Keown (2011) menjelaskan terdapat hubungan antara tingkat pendapatan dengan pengetahuan keuangan. Hal ini menunjukan bahwa orang tua dengan pendapatan rumah tangga yang lebih tinggi cenderung memiliki tingkat literasi keuangan yang lebih tinggi karena mereka lebih sering menggunakan instrumen dan layanan finansial.Personal income adalah total pendapatan kotor tahunan seorang individu yang berasal dari upah, perusahaan bisnis dan berbagai investasi. Personal income adalah indikator yang baik untuk permintaan konsumen masa depan, meskipun tidak sempurna (Hilgert, et al., 2003).

Lama berusaha. lama usaha adalah lama waktu yang sudah dijalani pedagang dalam menjalankan usahanya dan dalam lama nya seseorang tersebut dalam berusaha dapat mempengaruhi pengetahuan seseorang terhadap bidang usahanya termasuk di dalamnya adalah dalam bidang keuangan.

Usia. usia mempunyai korelasi lansung terhadap literasi keuangan, semakin bertambah umur dan pengalaman bekerja maka akan semakin banyak informasi yang diperoleh tekait dengan masalah keuangan, the social research centre (2011) menemukan bahwa terdapat hubungan antara usia dengan tingkat literasi keuangan.

Berdasarkan tinjauan dan kajian terhadap penelitian terdahulu yang relevan, maka hipotesis yang akan diujikan kebenarannya secara empiris adalah Diduga faktor demografi yang terdiri dari Tingkat Pendidikan, Tingkat Pendapatan, Lama Berusaha Dan Usia berpengaruh signifikan terhadap Literasi Keuangan pada pelaku UMKM bengkel sepeda motor Kec. Siak Hulu Kab.Kampar.

\section{METODE PENELITIAN \\ Lokasi / Objek Penelitian}

Penelitan ini dilakukan di Kecamatan Siak hulu karena kecamatan ini merupakan kecamatan yang berbatasan dengan kota Pekanbaru dan merupakan kecamatan yang memiliki paling banyak jumlah UMKM jenis Biro Dan Jasa yaitu sebanyak 366 unit usaha.

Tabel 3. Operasional Variabel

\begin{tabular}{|c|c|c|c|}
\hline VARIABEL & DIMENSI & INDIKATOR & SKALA \\
\hline $\begin{array}{l}\text { Literasi Keuangan, adalah adalah rangkaian } \\
\text { proses atau aktivitas untuk meningkatkan } \\
\text { pengetahuan, keyakinan, dan keterampilan } \\
\text { konsumen dan masyarakat luas sehingga } \\
\text { mereka mampu mengelola keuangan } \\
\text { dengan lebih baik (Surat Edaran Otoritas } \\
\text { Jasa Keuangan, 2014) }\end{array}$ & & $\begin{array}{l}\text { - } \text { Basic Personal Finance } \\
\text { - Manajemen Uang } \\
\text { - Utang dan Kredit } \\
\text { - Tabungan dan Investasi } \\
\text { - } \text { Manajemen Risiko }\end{array}$ & Nominal \\
\hline $\begin{array}{l}\text { Faktor Demografi, merupakan gambaran } \\
\text { mengenai latar belakang seseorang } \\
\text { sehingga dapat mempengaruhi } \\
\text { literacy mereka (Mandel, 2008). }\end{array}$ & $\begin{array}{l}\text { Tingkat } \\
\text { Pendidikan } \\
\text { - } \quad \text { Tingkat } \\
\text { Pendapatan } \\
\text { - Lama } \\
\text { Berusaha }\end{array}$ & $\begin{array}{ll}\text { - } & \text { Tidak lulus } \\
\text { - } & \text { SMA/Sederajat } \\
\text { - } & <4.000 .000 \\
\text { - } & >4.000 .000 \\
\text { - } & <5 \text { Tahun } \\
\text { - } & >5 \text { Tahun }\end{array}$ & Nominal \\
\hline
\end{tabular}




\begin{tabular}{lll}
\hline & $\bullet$ Usia & $<30$ tahun \\
& $\bullet>30$ tahun \\
\hline
\end{tabular}

Sumber : Data olahan (2018)

\section{Populasi}

Populasi dalam penelitian ini adalah seluruh pelaku UMKM bengkel sepeda motor di Kecamatan Siak Hulu yang berjumlah sekitar 110 unit usaha UMKM bengkel sepeda motor

\section{Sampel}

Teknik pengambilan sampel yang dilakukan dengan metode purposive sampling, yaitu pemilihan sampel bedasarkan kriteria. Mengingat populasi jumlah dan jenis usahanya sangat banyak dan beragam, maka penulis mengambil sampel dengan menggunakan kriteria sebagai berikut :

a. Sudah menjalankan usaha lebih dari 1 tahun.

b. Masuk dalam kategori Livelihood Activities, yaitu UMKM yang digunakan sebagai kesempatan kerja untuk mencari nafkah, yang lebih umum dikenal sebagai sektor informal.

c. Lokasi objek penelitian yang diambil hanya diKecamatan Siak Hulu.

Berdasarkan kriteria diatas karena keterbatasan waktu dan kemampuan penulis maka metode penentuan jumlah pengambilan sampel adalah dengan menggunakan Rumus Slovin.

$\underline{\text { Rumus Slovin }}$

dimana :

$$
n=\frac{N}{1+N \alpha^{2}}
$$

$\mathrm{n}=$ Jumlah Sampel

$\mathrm{N}=$

Jumlah Populasi

$\alpha=$ batas toleransi kesalahan /

error tolerance (dalam persen).

Untuk menggunakan rumus ini,

pertama ditentukan berapa batas

toleransi kesalahan. Batas toleransi

kesalahan ini dinyatakan dengan

persentase. Semakin kecil toleransi kesalahan, semakin akurat sampel menggambarkan populasi (Dalam Anwar Sanusi, Metodologi Penelitian Bisnis, Salemba Empat 2011).

$$
n=\frac{110}{1+\left(110 \times 0,1^{2}\right)}=52
$$

Adapun jumlah populasi yang ada di Kecamatan Siak Hulu yang bergerak pada sektor Jasa Bengkel Sepeda Motor adalah sebesar 110 UMKM dengan batas toleransi kesalahan (a) $10 \%$, dan jumlah sampel yang digunakan dalam penelitian ini adalah sebanyak 52 UMKM.

\section{HASIL DAN PEMBAHASAN}

AnalisisTingkat Literasi Keuangan Pada Pelaku usaha UMKM Bengkel SepedaMotor Di Kec. Siak Hulu Kab.Kampar

Data yang di teliti dikelompokkan ke dalam dua kategori, yaitu tingkat literasi keuangan tinggi dan tingkat literasi rendah, dengan menyusun interval data sebagai berikut :

$$
\begin{aligned}
& \text { Interval } \\
& =\frac{\text { Nilai tinggi }- \text { Nilai Rendah }}{\text { Banyak Kelas }} \\
& \text { Interval }=\frac{26-0}{2}=13
\end{aligned}
$$

\begin{tabular}{|c|c|}
\hline Interval data & Kategori \\
\hline $0-13$ & Rendah \\
\hline$>13$ & Tinggi \\
\hline
\end{tabular}

Sehingga diperoleh data interval sebagai berikut :

Tabel 4.Interval Data

tersebut kemudian dijadikan dasar untuk melakukan analisis statistik. Analisis regresi logistik biner digunakan untuk menguji sejauh mana tingkat pendidikan, tingkat pendapatan, lama usaha dan usia mempengaruhi tingkat literasi keuangan 
pelaku usaha bengkel sepeda motor di Kecamatan Siak Hulu Kabupaten Kampar.

Variabel tingkat literasi keuangan merupakan varibel dummy yang mempunyai dua kategori dan dinyatakan angka 1 dan 0 . Angka 1 untuk kategori tinggi dan 0 untuk kategori rendah. Daftar sampel pemilik usaha yang memperoleh skor tingkat literasi keuangan tinggi dan rendah ditampilkan di lampiran. Tingkat literasi keuangan menunjukkan kemampuan seseorang untuk memenuhi dan mengevaluasi informasi yang relevan dalam mengambil keputusan, dengan memahami kusekuensi finansial yang di timbulkan.

Pelaku usaha yang memperoleh skor tingkat literasi yang keuangan yang tinggi, berarti mereka dapat mengevaluasi dan informasi yang relevan dalam pengambilan keputusan dengan memahami kosekuensi financial yang ditimbulkan juga tinggi. Apa bila tingkat literasi keuangan tinggi maka ketahanan suatu usaha akan lebih terjamin.

Hal- hal yang diperiksa dalam menilai literasi keuangan para pelaku usaha antara lain berkaitan dengan pengetahuan umum keuangan, perbankan, asuransi dan investasi. Para pelaku usaha yang memiliki tingkat literasi keuangan yang rendah, belum cukup memahami dan dan belum mampu mengevaluasi informasi yang relevan dalam pengambilan keputusan, serta kurang memahami kosekuensi financial yang ditimbulkan. Ketahanan usaha mereka pun belum terjamin.

Uji hipotesis yang pertama untuk melihat bagaimana tingkat literasi keuangan pelaku usaha di Kecamatan Siak Hulu. Dari 50 sampel tersebut dikelompokkan atau dikategorikan berdasarkan skor tingkat literasi yang diterimanya, yaitu kelompok pemilik usaha yang memperoleh skor tingkat literasi keuangan tinggi dan pemilik usaha dengan skor tingkat litersai keuangan yang rendah, dicari menggunakan crosstabulation antara tingkat literasi keuangan dengan faktorfaktor yang mempengaruhi (tingkat pendidikan, tingkat pendapatan, lama usaha, dan usia). Dapat dilihat pada tabel distribusi pemilik usaha adalah sebagai berikut ini :

Table 5 Distribusi Pelaku Usaha Bengkel

\begin{tabular}{ccccccc}
\hline Literasi & \multicolumn{2}{c}{ Tingkat Pendidikan } & \multicolumn{3}{c}{ Tingkat Pendapatan } \\
\hline Tinggi & 9 & 17 & $\mathbf{2 6}$ & 19 & 7 & $\mathbf{2 6}$ \\
\hline Rendah & 12 & 12 & $\mathbf{2 4}$ & 12 & 12 & $\mathbf{2 4}$ \\
\hline Total & $\mathbf{2 1}$ & $\mathbf{2 9}$ & $\mathbf{5 0}$ & $\mathbf{3 1}$ & $\mathbf{1 9}$ & $\mathbf{5 0}$ \\
\hline Literasi & & Lama berusaha & & & Usia & \\
\hline Tinggi & 12 & 14 & $\mathbf{2 6}$ & 10 & 16 & $\mathbf{2 6}$ \\
\hline Rendah & 14 & 10 & $\mathbf{2 4}$ & 13 & 11 & $\mathbf{2 4}$ \\
\hline Total & $\mathbf{2 6}$ & $\mathbf{2 4}$ & $\mathbf{5 0}$ & $\mathbf{2 3}$ & $\mathbf{2 7}$ & $\mathbf{5 0}$ \\
\hline
\end{tabular}

Sumber: Data Olahan, (2018)

Daritabel diatas dapat dilihat bahwa pelaku usaha yang memperoleh skor tingkat literasi yang tinggi adalah sebanyak 24 orang atau sebesar $48 \%$.Sedangkan, pemilik usaha yang memiliki tingkat skor literasi keuangan yang rendah adalah sebanyak 26 orang atau sebesar $52 \%$. Dan juga dapat dilihat bahwa pengusaha yang miliki tingkat pendidikan yang tidak sampai ke jenjang SMA sederajat hanya sedikit yaitu berkisar 21 orang.

Jadi dapat disimpulkan didalam penelitian ini bahwa pelaku usaha 
perbengkelan sepeda motor di Kecamatan Siak Hulu di dominankan oleh orang yang meiliki lulusan SMA sederajat dari pada yang tidak lulusan SMA sederajat dengan jumlah responden yang memiliki kategori tingkat literasi keuangan yang tinggi sama-sama pada angka 12.

Dari segi tingkat pendapatan di dominankan oleh pelaku usaha yang memiliki tingkat pendapatan yang dibawahRp.4.000.00 dari pada yang memiliki tingkat pendapatan diatas 4.000.000 perbulannya yaitu sebanyak 31 pengusaha berbanding dengan 19 pengusaha dengan kategori tingkat literasi keuangan yang tinggi yaitu samasama pada angka 12.

Untuk variabel lama berusaha lebih di dominankan oleh pelaku usaha yang memiliki lama usaha kurang dari 5 tahun dibandingkan pengusaha yang memiliki lama usaha diatas 5 tahun yaitu sebanyak 26 pengusaha berbanding 24 pengusaha dengan kategori tingkat literasi keuangan yang tinggi yaitu 14 pengusaha untuk responden yang menjalani usaha dibawah 5 tahun dan 10 pengusaha untuk responden yang menjalani usaha diatas 5 tahun.

Dan untuk usia pada pelaku usaha bengkel sepeda motor di Kecamatan Siak Huluantara pelaku usaha yang berusia lebih dari 30 tahun dan kurang dari 30 tahun diantara keduanya lebih di dominankan oleh pelaku usaha yang berumur lebih dari 30 tahun yaitu sebanyak 27 pengusaha dengan kategori tingkat literasi keuangan yang tinggi yaitu sebanyak 11 pengusaha.

Berdasarkan dari analisis deskriptif yang dilakukan dengan melakukan crosstabulation antara faktorfaktor demografi seseorang ( tingkatpendidikan, tingkat pendapatan, lama berusaha dan usia) terhadap tingkat literasi keuangan yang diangkat pada penelitian ini. Dapat dilihat bahwa dalam penelitian ini jumlah responden yang lulus SMA sederajat jauh lebih banyak jika dibandingkan responden yang tidak berkelulusan SMA sederajat yang diambil secara acak.

Dilihat dari segi tingkat pendapatan jumlah responden yang memiliki pendapatan perbulannya diatas Rp.4000.000 lebih sedikit jika di bandingkan dengan responden yang memiliki pendapatan yang kurang dari Rp.4000.000. Dari segi lama usaha responden yang sudah menempuh usaha yang kurang dari 5tahun lebih banyak dibandingkan dengan responden yang menempuh usaha yang lebih dari 5tahun. Dan dari segi usia terdapat bahwa responden yang memiliki usia diatas 30tahun lebih banyak jika dibandingkan dengan respnden yang memiliki usia dibawah 30tahun.

Pelaku usaha yang memperoleh skor tingkat literasi yang tinggi adalah sebanyak 24 orang dengan persenatse sebesar $48 \%$. Sedangkan, pemilik usaha yang memiliki tingkat skor literasi keuangan yang rendah adalah sebanyak 26 orang dengan persentase sebesar 52 $\%$. Maka darihasil pengujian yang dilakukan pada penelitian ini menunjukkan bahwa tingkat literasi keuangan pada pelaku UMKM bengkel sepeda motor di kecamatan siak hulu kabupaten Kampar termasuk kedalam kategori yang rendah atau lemah dengan persentase 48\%.Dan ini menunjukkan bahwa pengetahuan financial pada pelaku usaha UMKM bengkel sepeda motor di kecamatan siak hulu kabupaten Kampar masih dalam kondisi yang kurang optimal dan perlu ditingkatkan lagi.

Memiliki literasi keuangan yang baik bagi pelaku usaha sangatlah penting karena dengan semakin tingginya tingkat literasi keuangan seseorang akan membawa seseorang tersebut dapat 
terdorong dalam melibatkan usahanya ke pihak perbankan, contoh sederhana nya adalah dengan melakukan peminjaman kredit terhapat pihak bank untuk penambahan modal usaha nya sehingga usaha yang dimiliki dapat lebih maju dan berkembang.

Alasan beberpa pelaku usaha bengkel sepeda motor di kec.siak kab.kampar tidak melibatkan usahanya ke dalam sektor perbankan karena mereka banyak yang belum tahu bagaimana dengan memanfaatkan layanan perbankan dapat memajukian usaha mereka, kebanyakan pemikiran mereka menganggap memanfaatkan layanan perbankan hanya memberatkan langkah lahkah usaha nya dan itu di pengaruhi oleh lingkungan yang ada disekitar mereka yang masih beranggapan seperti itu.

Contoh sederhana dari bagaimana pengaruh literasi keuangan bagi pelaku usaha dapat mempengaruhi kemajuan usahanya adalah sebagaiman sebagian bersar dari pelaku usaha bengkel sepeda motor di Kec.Siak Hulu Kab.Kampar adalah merupakan usaha bengkel yang kecil, mereka mendapatkan pasokan barang persedian dengan membeli nya ke bengkel yang lebih besa yang persediaan banrang nya lebih banyak, pemasok barang persediaan terbesar atau bisa disebut dengan istilah pemasok pusat untuk barang perbengkelan tidak ada di pekanbaru hanya ada diluar kota dan kebanyakan bengkel yang skala besar memsan barang di pemasok pusat yang harganya lebih murah dan pemsaok pusat yang terdekat ada di batam.

Banyak selisih harga jika kita membeli barang secara lansung ke pemasok pusat dengan pemasok bengkel yang skala besar, dan selisih harga ini bisa di manfaatkan oleh pelaku usaha yang dalam skala kecil, namun kenyataan nya untuk pelaku usaha bengkel yang kecil di Kec.Siak Hulu
Kab. Kampar masih belum melakukan pembelian barang persedian ke pemasok pusat.

Dengan alasan melakukan pemesanan barang persediaan ke pemasok pusat lebih sulit karena melakukan transakasi yang menggunakan pegiriman uang dan kebanyakan dari meerka masih belum paham tentang itu sehingga mereka membatasi diri mereka untuk melakukan pemesanan barang dengan cara tersebut.

Disini peran literasi keuangan sangat dibutuhkan karena dengan pemahaman keuangan seseorang bisa melakukan pengenbangan usahanya lebih dari yang dilakukan oleh usaha kebanyakan orang, pemahaman literasi keuangan baiksangatlah dibutuhkan oleh pelaku usaha karena dengan memiliki literasi keuangan yang tinggi pengusaha dapat melibatkan usaha pada pihak perbankan untuk kemajuan usahanya.

Dalam penanganan dan penanggulangan akan minimnya tingkat literasi keuangan pada pelaku UMKM bengkel sepeda motor mestinya perlu diadakan, banyak hal yang bisa dilakukan seperti dengan memberikan seminar-seminar kepada pelaku usaha, atau pihak perbankan yang harus lebih giat dengan melakukan pengenalan kepada para pengusaha agar mereka memiliki dorongan terhadap keinginan hati mereka untuk mau memanfaatkan pendapatan yang mereka miliki dan lebih bisa mengelola aset mereka agar tidak terjadi pemborosan yang bersipat pengeluaran uang yang secara sia-sia.

Dalam hal ini pihak OJK pekanbaru dalam kegiatan pertandingan stocklab antara mahasiswa di pekanbaru juga menyampaikan beberapa hasil dari penelitian yang mereka lakukan tentang literasi keungan dikalangan UMKM. Dari pemaparan yang disampaikan oleh OJK tersebut dikemukakan bahwa tingkat literasi keungan di kalangan 
UMKM masih rendah dan salah satu cara yang dapat di lakukan oleh pihak OJK adalah dengan membuat game simulasi berinvestasi untuk mahasiswa karena mahasiswa merupakan calon pengusaha dimasa yang akan datang.

Maka dari game tersebut setiap permain akan diasah tingkat kemampuannya agar bisa memiliki keahlian dalam berinvestasi baik itu di reksadana dan juga dari saham yang terdiri dari beberapa sektor, disitu pemain juga ditingkatkan kemampauannya dalam bagimana memahami istilah-istilah dalam dunia keuangan, bagaimana memfaatkan peluang yang ada pada saham, dan bagaimana mengendalikan resiko ketika kita memegang saham.Sehingga dengan simulasi dari game ini dari pihak OJK mengharapkan agar para pemain dapat memahami bagaimana cara mengelola aset dalam meningkatkan pendapatan sesorang dengan memanfaatkan produk yang ditawarkan oleh perbankan dan instrument keuangan lainnya.

Dari pihak OJK sendiri juga disampaikan bahwa di buatnya suatu game simulasi ini, bertujuan agar mahasiswa tersebut juga menyampaikan nya kepada teman-temannya dan kepada masyarakat yang banyak, sehingga suatu game tersebut dapat digemari oleh orang banyak dan secara tidak lansung orang tersebut telah mendapatkan ilmu tentang keuangan, pihak OJK berketekat agar tingkat literasi keuangan pada masyarakat indonesia meningkat maka pertandingan game ini ini dilakukan hampir disemua provinsi yang ada di Indonesia.

Dan terlebih lagi dalam pertandingan ini pihak OJK juga membawa beberapa mentor dari perusahan sekuritas yang akan menuntun cara dalam berinvestasi di dalam saham dan menganjurkan kepada mahasiswa agar selepasnya mahasiswa tersebut dari perkuliahan dan memasuki dunia kerja diharapkan untuk mau mendalami ilmu tentang dunia perbankan sehingga kedepannya mereka mau melibatkan usahanya pada dunia perbankan sehingga minimnya pelaku usaha yang memiliki tingkat literasi keuangan yang tinggi dapat teratasi.

Untuk rendahnya tingkat literasi pada kalangan UMKM bengkel sepeda motor di kecamatan siak hulu ini, terdepat beberapa alasan yang menyebabkan perhatian dalam hal ini. Alasan pertama, keterbukaan bagi pelaku usaha untuk hadir pada lembaga perbankan dan asuransi masih kurang, dan rendahnya akses pelaku usaha ke sektor perbankan dan asuransi disebabkan karena pelaku usaha masih merasa kurang memiliki mamfaat ketika memiliki rekening perbankan dan asuransi sehigga membatasi keinginan untuk memiliki dan memakai memamfaat dan fasilitas yang ditawarkan oleh perbankan danasuransi, ada juga sebagian yang merasa tidak memiliki jaminan untuk meminjam uang pada sektor perbankan dan asuransi.

Alasan yang lainnya, pada pelaku UMKM bengkel sepeda motor di kecamatan siak hulu sebagian besar merupakan orang yang bertamatan SMA dan SMK mekanik yang mana saat mereka masih di bangku sekolah, mereka masih kurang mendapatkan muatan materi mengenai financial. Pendidikan personal finance khususnya di Indonesia belum termasuk kedalam kurikulum untuk pendidikan menengah keatas dan menengah pertama, sementara sebagian besar responden berpendidikan menengah keatas dan menengah pertama.

Meskipun memperoleh mata pelajaran ekonomi, namun mata pelajaran tersebut belum memiliki muatan pendidikan yang mampu meningkatkan personal finance.Dan 
mereka hanya diajarkan materi yang yang harus dikuasai untuk memperoleh pekerjaan, mereka tidak diajarkan mengelola uang yang mereka peroleh selama bekerja.

Pengaruh Tingkat Pendidikan, Tingkat Pendapatan, Lama Berusaha dan Usia Terhadap Literasi Keuangan

Analisis multivariat dengan menggunakan regresi logistic biner (binary logistic regression).Regresi logistic biner digunakan untuk menguji hipotesis dalam penelitian ini karenavariabel devendennya merupakan variable katagorikal yang mempunyai dua kategori (dummy variable) sehingga tidak dapat diselesaikan dengan menggukan regresi berganda. Teknik ini tidak memerlukan lagi uji normalitas pada variable bebasnya.

Uji regresi logistic mengabaikan heteroscedasity, artinya variable dependen tidak memerlukan homoscedasity untuk masing-masing variable independennya. Tujuan dari pengujian asumsi klasik yang meliputi uji normalitas, multikoloneaitas dan heteroskedastisitas adalah agar model analisis regresi yang dipakai dalam penelitian menghasilkan niali parametrik yang sahih.

Pengujian

hipotesis

menggunakan regresi logistic tidak memerlukan pengujian asumsi klasik karena sebelum pengujian hipotesis dilakukan langkah pertama yang dilakukan adlah menilai kelayakan model regresi dan menilai model fit. Fungsi dari menilai kelayakan model regresi dan meniali model fit merupakan pengganti dari uji asumsi klasik.
Regresi logistic dalam penelitian ini digunakan untuk menguji pengaruh tingakt pendidikan, tingkat pendapatan, lama usaha dan usia terhadap kalangan Umkm perbengkelan sepeda motor di Kecamatan Siak Hulu Kabupaten Kampar. Pengujian dilakukan pada tingkat signifikansi $(\alpha)$ sebesar $5 \%$ $(0,05)$.

\section{Menguji kelayakan regresi}

Analisis pertama yang dilakukan adalah menilai kelayakan model regresi logistic yang akan digunakan. Kelayakan model regresi yang dinilai dengan homer and lomeshow's goodness of fit test. Homer and lomeshow's goodness of fit test adalah untuk menguji hipotesis nol bahwa data empiris cocok atau sesuai dengan model ( tidak ada perbedaaan antara model dengan data sehingga model dapat dikatakan fit).

Jika nilai homer and lomeshow's goodness of fit test. sama dengan atau kurang dari 0,05 maka hipotesis nol ditolak yang berarti ada perbedaan signifikan antara model yang dinilai dengan observasi sehingga goodness fit model tidak baik karena model tidak dapat memprediksi nilai observasinya. Jika nilai homer and lomeshow's goodness of fit teststatistics lebih besar dari 0,05 maka hipotesis nol tidak dapat dikatakan ditolak yang berarti model mampu memprediksi nilai observasinya atau dapat dikatakan model diterima karena sesuai dengan observasinya. Pengujian menggunakan homer and lomeshow's goodness of fit test. homer and lomeshow's goodness of fit test ditampilkan dalam tabel 5.4.1 di bawah ini.

\begin{tabular}{|c|c|c|c|}
\hline \multicolumn{4}{|c|}{ Tabel 6 hosmer and lomeshow test } \\
\hline Step & Chi-square & df & Sig. \\
\hline 1 & 2,989 & 8 & .935 \\
\hline
\end{tabular}

Sumber : Data Olahan, (2018
Dari tabel diatas menunjukkan bahwa besarnya nilai statistic hosmer and lomeshow test of fit sebesar 2,989 dengan tingkat probabilitas 0,935 yang nilai nya jauh lebih besar dari diatas 0,05 maka Ho diterima, sehingga model menjelaskan hipotesis fit dengan data dan layak diajukan dalam regresi 
Uji Hipotesis Tingkat Pendidikan, Tingkat Pendapatan, Lama Berusaha Dan Usia Terhadap Literasi Keuangan

Pengujian ini dilakukan dengan derajat kebebasan sebesar 5\% atau 0,05 agar kemungkinan terjadinya ganguan kecil dan umum digunakan. Berikut ini merupakan hasil pengujian hipotesis factor-faktor yang mempengaruhi tingkat literasi keuangan di kalangan pelaku usaha di Kecamatan Siak Hulu Kabupaten Kampar.

\begin{tabular}{|c|c|c|c|c|c|c|c|}
\hline \multicolumn{8}{|c|}{ Tabel 9. Variables in the Equation } \\
\hline & & $\mathrm{B}$ & S.E. & Wald & $\mathrm{df}$ & Sig. & $\operatorname{Exp}(B)$ \\
\hline \multirow[t]{5}{*}{ Step $1^{\text {a }}$} & Pendidikan &,- 737 & ,661 & 1,241 & 1 & ,265 &, 479 \\
\hline & Pendapatan & 1,668 & ,733 & 5,175 & 1 &, 023 & 5,304 \\
\hline & Lama_berusaha &,- 496 & ,643 & 594 & 1 & ,441 & 609 \\
\hline & Usia & $-1,178$ & ,695 & 2,874 & 1 & ,090 & ,308 \\
\hline & Constant &, 572 & 598 & ,915 & 1 &, 339 & 1,772 \\
\hline
\end{tabular}

a. Variable(s) entered on step 1: Pendidikan, Pendapatan, Lama_usaha, Usia.

Sumber : Data Olahan, (2018)

$\operatorname{In}(\rho / 1-\rho)=0,572-0,737$ Pendidikan + 1,668 Pendapatan - 0,496 Lama Usaha 1,178 Usia

Odds merupakan rasio peristiwa yang sekarang terjadi dan peristiwa yang mungkin terjadi. Odds seringkali disebut dengan probibalitas, odds dan probabilitas mempunyai informasi yang sama, tetapi dalam bentuk yang berbeda.

1. Hasil pengujian menunjukkan angka konstanta sebesar 0,572 yang artinya jika variabel lain (tingkat pendidikan, tingkat pendapatan, lama usaha dan usia) sama dengan nol maka tingkat literasi keuangan mengalami kenaikan sebesar 0,572.

2. Variabel tingkat pendidikan (X1) memiliki koefisien regresi sebesar 0,737 yang berarti bahwa jika variabel tingkat pendidikan mengalami peningkatan sebesar satu satuan odds maka tingkat literasi keuangan akan mengalami penurunan sebesar 0,737 dengan asumsi variabel lain tetap.

Hipotesis 1 : tingkat pendidikan berpengaruh terhadap tingkat literasi keuangan di kalangan pelaku UMKM bengkel sepeda motor di Kecamatan Siak Hulu Kabupaten Kampar. Hasil pengujian menunjukkan bahwa variabel bebas tingkat pendidikan dengan tingkat literasi keuangan di kalangan pelaku usaha bengekel sepeda motor di Kecamatan Siak Hulu Kab Kampar diperoleh nilai signifikansi sebesar 0,265 . Niali signifikan tersebut lebih besar dari 0,05 sehingga dapat disimpulkan bahwa tingkat pendidikan tidak berpengaruh terhadap literasi keuangan di kalangan pelaku UMKM bengkel sepeda motor di Kecamatan Siak Hulu Kabupaten Kampar, maka hipotesis ini ditolak.

3. Variabel tingkat pendapatan (X2) memiliki koefisien regresi sebesar 1,668 artinya jika varibel tingkat pendapatan mengalami peningkatan sebesar satu satuan makaodss tingkat literasi keuangan mengalami peningkatan sebesar 1,668 dengan asumsi variabel yang lain tetap.

Hipotesis 2 : tingkat pendapatan berpengaruh terhadap tingkat literasi keuangan di kalangan pelaku UMKM bengkel sepeda motor di Kecamatan Siak Hulu Kabupaten Kampar.

Hasil pengujian terhadap variabel bebas tingkat pendidikan dengan tingkat literasi keuangan di kalangan UMKM bengkel sepeda motor di kecamatan siak hulu kabupaten Kampar di peroleh nialai signifikansi 
sebesar 0,023. Niali signifikansi tersebut lebih kecil dari 0,05 sehingga dapat disimpulkan bahwa tingkat pendapatan berpengaruh terhadap literasi keuangan di kalangan pelaku UMKM bengkel sepeda motor di Kecamatan Siak Hulu Kabupaten Kampar, maka hipotesis ini diterima.

4. Variabel lama berusaha (X3) memiliki koefisien regresi sebesar 0,496 artinya jika varibel tingkat pendapatan mengalami peningkatan sebesar satu satuan maka odss tingkat literasi keuangan mengalami penurunan sebesar 0,496 dengan asumsi variabel yang lain tetap.

Hipotesis 3 : lama berusaha berpengaruh terhadap tingkat literasi keuangan di kalangan pelaku UMKM bengkel sepeda motor di Kecamatan Siak Hulu Kabupaten Kampar.

Hasil pengujian terhadap variabel bebas lama usaha dengan tingkat literasi keuangan di kalangan UMKM bengkel sepeda motor di kecamatan siak hulu kabupaten Kampar di peroleh nialai signifikansi sebesar 0,441. Nilai signifikansi tersebut lebih besar dari 0,05 sehingga dapat disimpulkan bahwa tingkat pendapatan tidak berpengaruh terhadap literasi keuangan di kalangan pelaku UMKM bengkel sepeda motor di Kecamatan Siak Hulu Kabupaten Kampar, maka hipotesis ini ditolak.

5. Variabel Usia (X4) memiliki koefisien regresi sebesar $-1,178$ yang berarti bahwa jika variabel Usia mengalami peningkatan sebesar satu satuan odds maka tingkat literasi keuangan akan mengalami penurunan sebesar 1,178 dengan asumsi variabel lain tetap.

Hipotesis 4 : Usia berpengaruh terhadap tingkat literasi keuangan di kalangan pelaku UMKM bengkel sepeda motor di Kecamatan Siak Hulu Kabupaten Kampar.

Hasil pengujian menunjukkan bahwa variabel bebas Usia dengan tingkat literasi keuangan di kalangan pelaku usaha bengekel sepeda motor di Kecamatan Siak Hulu Kab.Kampar diperoleh nilai signifikansi sebesar 0,090. Niali signifikan tersebut lebih besar dari 0,05 sehingga dapat disimpulkan bahwa variabel usia tidak berpengaruh terhadap literasi keuangan di kalangan pelaku UMKM bengkel sepeda motor di Kecamatan Siak Hulu Kabupaten Kampar, maka hipotesis ini ditolak.

Kegiatan pengukuran tingkat literasi mendukung informasi tentang tingkat pendidikan, tingkat pendapatan, lama usaha dan usia. Komponen yang terdapat pada literasi keuangan yaitu pengetahuan umum keuangan, perbankan, asuransi, dan investasi. Melalui komponen tersebut, dapat di peroleh suatu indicator yang menunjukkan posisi, kondisi pengetahuan keuangan sebenarnya pelaku usaha di Kecamatan Siak Hulu Kabupaten Kampar .hasil pengujian yang telah dilakukan diatas menunjukkan bahwa :

Pengaruh Tingkat Pendidikan Terhadap Literasi Keuangan Pada Pelaku Usaha Bengkel Sepeda Motor Di Kec. Siak Hulu

Hasil pengujian menunjukkan bahwa tingkat pendidikan tidak berpengaruh signifikan terhadap literasi keuangan pada pelaku UMKM bengkel sepeda motor di kecamatan siak hulu kabupaten Kampar. Dengan berdasarkan hasil pengujian regresi logistik biner yang terlihat pada Tabel 5.4.4 didapatkan nilai koefisien regresi sebesar $-0,737$ pada tingkat signifikansi sebesar 0,265Sehingga $\mathrm{H} 0$ di terima dan $\mathrm{H} 1$ ditolak, karena nilai signifikansi yang 
melebihi dari 0,05 maka dapat disimpulkan bahwa hipotesis ini di tolak.

Hasil dari penelitian ini berbeda dengan hasil penelitian yang dilakukan oleh Della Cahya Kamila (2015) yang mengemukakan bahwa pendidikan berpengaruh positif dengan tingkat literasi keuangan dan berbeda juga dengan penelitian yang dilakukan oleh Risky Amaliyah (2015) yang mengemukakan bahwa tingkat pendidikan berpengaruh terhadap literasi keuangan seseorang dengan nilai koefisien regresi sebesar 4,119 dan pada tingkatan signifikansi sebesar 0,000.

Namun penelitian ini memiliki kesamaan dengan penelitian yang dilakukan oleh Farah Margarheta (2015) yang mengemukakan pendidikan tidak berpengaruh terhadapat tingkat literasi keuangan seseorang dan penelitian ini juga memiliki kesamaan dengan penelitian yang dilakukan oleh Chintya Wijaya (2015) yang di dalam penelitian nya melakukan pengujian terhadap tingkat literasi keuangan pada

Warga di komplek tanah mas dan mengemukakan bahwa tingkat pendidikan tidak berpengaruh terhadap literasi keuangan sesorang, didalam penelitian tersebut didapatkan hasil koefisien regresi sebesar 0,294 dengan tingkatan signifikansi sebsar 0,299 sehingga hipotesis dalam penelitian tersebut ditolak.

Ada beberapa hal harus diperhatikan hasil dari pengaruh tingkat pendidikan terhadap literasi keuangan di kalangan UMKM bengkel sepeda motor di kecamatan siak hulu ini, yang pertama jika dipertimbangkan secara logika maka seharusnya suatu tingkat pendidikan haruslah berpengaruh terhadap tingkat literasi keuangan seseorang. Karena itu berlatar belakang kan dari suatu tingkat kemampuan berfikir seseorang, namun ada beberapa hal yang membuat variabel tingkat pendidikan ini tidak berpengaruh terhadap literasi keuangan pada pelaku UMKM bengkel sepeda motor di Kecamatan Siak Hulu Kabupaten Kampar.

Yang pertama karena dari pelaku usaha itu sendiri banyak yang tidak mengecam ilmu keuangan ketika mereka duduk di bangku sekolahnya dulu, materi di sekolah baik itu tingkat SMP dan SMA masih banyak yang besipat umum dan hanya sedikit menyinggung tentang ilmu keuangan, mereka hanya diajarkan sebagain kecil dari konsep-konsep dari ilmu keuangan seperti perhitungan bunga majemuk dan pengetahuan tentang pemakaian produk dari perbankan. Mereka lebih diajarkan tentang bagaimana cara untuk berwirausaha dan bekerja namun tidak tentang bagaimana cara memanfaatkan pendapatan yang mereka punya dengan menggunakan produk perbankan untuk memajukan usaha mereka.

Namun sekarang pihak OJK telah mengeluarkan buku yang berjudul Literasi Keuangan yang di peruntukkan untuk anak SMP, SMA dan perkuliaha sebagai penanggulangan terhadap masalah ini (www.ojk.go.id). Dan untuk saat ini buku yang berjudul Literasi Keuangan masih sulit didapatkan karna masih hanya beredar beberapa kota saja. Dengan adanya buku ini maka akan meningkatkan pemahaman akan ilmu keuangan para pelajar, dan pihak OJK juga berniat akan mengadakan seminar untuk bedah buku literasi keuangan bagi para pelajar agar mereka lebih berminat untuk mendalami pemahaman tentang pentingnya suatu literasi keuangan bagi seorang individu, terutama bagi golongan pelajar yang akan menempuh dunia kerja dan usaha dimasa depan mereka.

Maka dapat disimpulkan dari pernyataan diatas bahwa bukan berarti jika lembaga pendidikan tidak mengajari ilmu tentang keuangan dengan baik 
tetapi hanya saja tidak sepenuhnya untuk mencapai pada tingkat literasi keuangan yang maksimal, maka diharuskan bagi para pelajar itu sendiri untuk mencari ilmu tambahan mengenai ilmu keuangan agar kedepannya ketika mereka menjadi seorang pengusaha dapat mengelola dan menginvestasikan aset yang mereka punya dengan baik.

\section{Pengaruh Tingkat Pendapatan Terhadap Literasi Keuangan Pada Pelaku Usaha Bengkel Sepeda Motor Di Kec. Siak Hulu}

Hasil pengujian menunjukkan bahwa tingkat pendapatan berpengaruh signifikan terhadap literasi keuangan pada pelaku UMKM bengkel sepeda motor di Kecamatan Siak Hulu Kabupaten Kampar, berdasarkan hasil pengujian regresi logistik biner yang terlihat pada Tabel 5.4.4 didapatkan nilai koefisien regresi sebesar 1,668 pada tingkat signifiakansi sebesar 0,023 sehingga $\mathrm{H} 0$ di tolak dan $\mathrm{H} 1$ diterima. Maka dapat disimpulkan bahwa hipotesis ini diterima.

Penelitian ini bertentangan dengan penelitian yang dilakukan oleh Riski Amaliyah Dan Setyo Witiastuti (2015) yang mengemukakan hasil penelitian dengan nilai signifikansi pada tingkatan 0,074 yang menunjukkan bahwa lebih besar dari 5\% sehingga tingkat pendapatan tidak berpengaruh secara signifikan terhadap literasi keuangan pada pelaku UMKM Kota Tegal.

Penelitian ini memiliki kesesuaian dengan penelitian yang dilakukan oleh Lusardi Dan Mitchell (2011), Chen Dan Volpe (1998) yang menujukkan bahwa tingkat pendapatan berpengaruh terhadap tingkat literasi keuangan seseorang. Memang pada dasarnya jika seseorang memiliki tingkat literasi keuangan yang tinggi dan memiliki pendapatan yang tinggi maka mereka akan dengan mudah untuk masuk dan berinvestasi pada dunia perbankan dan lainnya, namun pada penelitian ini tingkat literasi keuangan pelaku usaha masih menunjukkan pada kategori yang rendah atau lemah.

Distribusi Pelaku Usaha menunjukkan bahwa pelaku usaha yang memiliki pendapatan kuraang dari 4.000.000 adalah sebanyak 31 dan hanya 12 pelaku usaha yang memiliki tingkat literasi keuangan yang tinggi atau sekitar $38 \%$. Sedangkan pelaku usaha yang memiliki tingkat pendapatan yang diatas 4.000.000 adalah sebanyak 19 pelaku usaha dan memiliki pelaku usaha yang mempunyai tingkat literasi keuangan yang tinggi sebanyak 12 pelaku usaha dengan persentase sebesar $63 \%$ yang menunjukkan bahwa semakin tinggi tingkat pendapatan maka akan berpotensi dalam meningkatkan literasi keuangan bagi pelaku usaha tersebut.

Dan pernyataan tersebut didukung oleh hasil pengujian statistik logistik yang terdapat pada Tabel 5.4.4 didapatkan koefisien sebesar 1,668 dengan tingkat signifikansi 0,023 menunjukkan bahwa pendapatan berpengaruh signifikan positif terhadap literasi keuangan, dan dapat disimpulkan dengan tingginya tingkat pendapatan pada pelaku usaha bengkel di kecamatan siak hulu mempengaruhi tingkat literasi keuangan mereka. Koefisien yang positif dengan angka yang lebih besar dari konstanta menguatkan jika suatu tingkatan pendapatan pada pelaku usaha mempengaruhi penambahan tingkatan literasi keuangannya.

Karena hasil pengujian deskriftif yang menunjukkan tingkat literasi keuangan mereka masih $48 \%$ dan tergolong rendah maka sebaiknya mereka perlu dibina lagi mengenai pentingnya pengetahuan keuangan, namun disini variabel tingkat pendapatan sudah bisa menjadi suatu hal sebagai tolak ukur dalam menunjang tingkat 
literasi keuangan di kalangan pelaku usaha bengkel sepeda motor di kec. Siak hulu.

Dan adapun hal-hal yang menyebabkan tingkat pendapatan mereka dapat mempengaruhi tingkat literasi keuangan mereka, bisa jadi karena pendapatan mereka yang semakin tinggi yang menyebabkan sebagian dari mereka menggunakan produk perbankan dan asuransi dan lembaga kredit lainnya sehingga mereka bisa memiliki pengetahuan keuangan, kepandaian dan kecakapan pribadi (personal finance) dalam mengetahui konsep keuangan dan mengelola aset yang mereka miliki sebagai jaminan usahanya dimasa yang akan datang.

\section{Pengaruh Lama Berusaha Terhadap Literasi Keuangan Pada Pelaku Usaha Bengkel Sepeda Motor Di Kec. Siak Hulu}

Hasil pengujian menunjukkan bahwa lama berusaha tidak berpengaruh terhadap tingkat literasi keuangan pada pelaku UMKM bengkel sepeda motor di Kecamatan Siak Hulu Kabupaten Kampar, dengan berdasarkan dari hasil pengujian regresi logistik biner yang terlihat pada Tabel 5.4.4 didapatkan nilai konstanta sebesar $-0,496$ pada tingkatan signifikansi sebesar 0,441 hasil signifiakansi yang lebih besar dari $5 \%$ yang menjadikan hasil dari penelitian ini tidak berpengaruh sehingga dapat disimpulkan bahwa H1ditolak dan $\mathrm{H} 0$ diterima.

Hasil pengujian ini bertentangan dengan hasil pengujian yang dilakukan oleh Dela Cahya Camelia (2012) yang meneliti tentang tingkat literasi keuangan bagi pelaku UMKM perempuan di kabupaten mempawah kalimantan barat, hasil pengujian menunjukkan bahwa lama usaha berpengaruh terhadap tingkat literasi keuangan dengan besarnya koefisen regresi 0,574 pada tingkat signifikansi sebesar 0,007. Namun hasil pengujian ini memiliki kesamaan dengan hasil pengujian yang dilakukan oleh Chintia Nur Ichwan (2016) yang mengemukakan bahwa lama usaha tidak berpengaruh terhadap tingkat literasi keuangan.

Hal-hal yang menyebabkan lama berusaha bisa mempengaruhi suatu tingkat literasi keuangan seseorang adalah karena semakin lama berusaha tersebut berdiri maka akan semakin banyak pengalaman yang dimiliki oleh pelaku usahanya, termasuk didalamnya adalah manajemen keuangan seperti pengelolaan keuangan dan juga dalam pengelolaan pengambilan keputusan keuangan. Maka dengan lama nya seorang pengusaha menjalani usaha maka kemampuan pengelolaan keuangan mereka akan meningkat.

Namun dalam hal tersebut bukan berarti jika mereka telah menjalani usaha dengan lama mereka sudah memiliki pemahaman keuangan yang baik, mungkin dalam mengatur keuangan dalam pengelolaan usaha, mereka sudah dalam kategori yang baik namun belum tentu pemahaman tentang konsep-konsep keuangan mereka sudah maksimal, karena tingkat literasi keuangan yang baik sampai kepada tingkatan dalam mengendalikan risiko keuangan, berinvestasi, cakap dalam memahami dan memakai produk-produk keuangan.

Dalam penelitian ini hasilnya menunjukkan tidak adanya pengaruh lama berusaha terhadap tingkat literasi keuangan pengusaha bengkel sepeda motor dikecamatan Siak Hulu, dengan tingkat signifikansi yang dapat diliht pada Tabel 5.4.4 yaitu sebesar 0,441 yang menunjukkan bahwa jauh lebih besar dari 5\%. Ketidak konsistenan hasil penelitian ini dengan penelitian terdahulu bisa jadi karena faktor dari kepribadian pelaku usaha itu sendiri.

Sebab banyak dari pelaku usaha perbengkelan sepeda motor tidak terlalu 
tertarik terhadap kemampuan pengelolaan aset dan keuangan mereka melainkan lebih terfokuskan kepada peningkatannya skill atau kemampuan mereka dalam menghadapi berbagai kerusakan motor, dan mereka juga kurang eksis dan aktif dalam melibatkan usaha nya kepada pihak perbankan, asuransi dan lain sebagainya, karena mereka kurang meperhatikan dan memperdalam pemahaman keuangannya sehingga hal ini yang bisa menjadi salah satu faktor penyebab lama usaha mereka tidak mempengaruhi tingkatan literasi keuangan mereka.

\section{Pengaruh Usia Terhadap Literasi Keuangan Pada Pelaku Usaha Bengkel Sepeda Motor Di Kec. Siak Hulu}

Hasil pengujian menunjukkan bahwa usia tidak berpengaruh terhadap literasi keuangan pada pelaku UMKM bengkel sepeda motor di Kecamatan Siak Hulu Kabupaten Kampar, dengan berdasarkan hasil pengujian regresi logistik biner yang dapat dilihat pada Tabel 5.4.4 didapatkan koefisien regresi sebesar $\quad-1,178$ pada tingkat signifikansi sebesar 0,090 maka dapat disimpulkan pada penelitian ini bahwa H0 diterima dan $\mathrm{H} 1$ ditolak dan hipotesis pada penelitian ini di tolak karena nilai signifikansi yang lebih besar dari $5 \%$.

Pengujian penelitian ini memiliki kesamaan hasil dengan pengujian yang dilakukan oleh Dela Cahya Camelia (2012) yang meneliti tentang tingkat literasi keuangan bagi pelaku UMKM perempuan di kabupaten mempawah kalimantan barat, hasil pengujian menunjukkan bahwa variabel usia tidak berpengaruh terhadap tingkat literasi keuangan dengan besarnya koefisien regresi negatif sebesar $-0,103$ pada tingkat signifikansi sebesar 0,194.

Tidak signifikannya variabel usia dengan pengujian signifikan sebesar 5\% tentunya tidak hanya dipengaruhi oleh usia sesorang itu saja, pasti ada juga faktor lain yang mungkin mempengaruhinya juga seperti faktor lingkungan, kebiasaan pribadi, sosialbudaya dan faktor-faktor pisikologis lainnya yang sulit diukur dan tidak dimasukkan kedalam penelitian ini.

\section{PENUTUP}

\section{Kesimpulan}

Berdasarkan hasil penelitian dan pembahasan pada bab sebelumnya maka dapat ditarik kesimpulan sebagai berikut:

1. Hasil pengujian untuk melihat apakah faktor demografi yang terdiri dari tingkat pendidikan, tingkat pendapatan dan lama berusaha dan usia berpengaruh secara signifikan terhadap literasi keuangan pada pelaku UMKM bengkel sepeda motor di Kec.Siak Hulu Kab.Kampar menunjukkan bahwa dari empat variabel yang diuji tersebut, terdapat tiga variabel yang tidak signifikan yaitu variabel tingkat pendidikan, lama berusaha, dan usia yang memiliki nilai signifikansi yang lebih besar dari pada 0,05 yang berarti bahwa hipotesis untuk ketiga variabel tersebut ditolak dan dapat disimpulkan bahwa tidak ada pengaruh antara tingkat pendidikan lama berusaha dan usia terhadap literasi keuangan pada pelaku usaha bengkel sepeda motor di kec.Siak Hulu Kab.Kampar, dan pada penelitian ini terdapat satu variabel yang signifikan yaitu variabel tingkat pendapatan dengan nilai signifikansi sebesar 0,023 yang lebih kecil dari 0,05 yang berarti bahwa hipotesis variabel tingkat pendapatan diterima dan dapat disimpulkan bahwa terdapat pengaruh antara tingkat pendapatan terhadap tingkat literasi keuangan 
pada pelaku usaha bengkel sepeda motor di kec.Siak Hulu Kab.Kampar.

2. Hasil dari analis menunjukkan bahwa tingkat literasi keuangan pada pelaku usaha bengkel sepeda motor di Kec.Siak Hulu Kab.Kampar masih tergolong kedalam kategori yang rendah, dilihat berdasarkan analisis deskriptif didapatkan bahwa pelaku usaha yang memperoleh skor tingkat literasi keuangan rendah adalah sebesar 52\%, sedangkan pemilik usaha bengkel sepeda motor di kec.Siak Hulu Kab.Kampar yang memperoleh skor tingkat literasi keuangan yang tinggi hanya sebesar $48 \%$. Karena persentase pelaku usaha yang memiliki skor tingkat literasi keuangan yang rendah lebih tinggi dibandingkan dari pada pelaku usaha memiliki skor tingkat literasi keuangan yang tinggi. Maka dari hasil pengujian tersebut dapat disimpulkan bahwa tingkat literasi keuangan pada pelaku usaha bengkel sepeda motor di Kec.Siak Hulu Kab.Kampar masih tergolong pada tingkatan yang rendah dan lemah dan dalam hal ini perlunya dilakukan pembinaan untuk pelaku usaha agar bisa membantu meningkatkan tingkat literasi keuangan bagi pelaku usaha bengkel sepeda motor di kec.siak hulu kab.kampar

\section{Saran}

Saran yang dapat diberikan dalam penelitian ini adalah sebagai berikut :

1. Pada penelitian ini masih banyak memiliki kekurangan dan harus di benahi lagi agar mendapatkan hasil yang optimal, sebaiknya dalam penelitian ini masih harus ditambahkan lagi referansi nya yang mendukung baik itu dari buku maupun dari jurnal yang ada, kekonsistenan dari banyak referensi maka akan membuat suatu penelitian lebih akurat.

2. Untuk penelitan selanjutnya sebaiknya juga dapat mencari dan menambah variabel penelitian, jumlah sampel baik dalam objek maupun rentan waktu penelitian, sehingga memiliki tingkat observasi yang lebih tinggi dan banyak yang lebih mencerminkan keadaan sesungguhnya.

3. Untuk pelaku usaha bengkel di kecamatan hulu, sebaiknya perlu menjaga dan meningkatkan kualitas usahanya dan melibatkan usahanya tersebut untuk eksis di dunia perbankan.

4. Bagi sektor eksternal baik itu pihak pemerintah, perbankan maupun OJK sebaiknya melakukan sosialisasi terhadap pelaku usaha bengkel yang ada dikecamatan siak hulu baik itu berupa pembinaan untuk meningkatkan literasi keuangan mereka dengan memberikan edukasi mengenai keuangan.

\section{DAFTAR PUSTAKA}

Cole By S. dan N. Fernando. (2008).Assesingthe Importance ofFinancial Literacy. ADB Financial For The Poor A Quarterly Newsletter of The Focal Point for Microfinace. September 2008. 9(3)

Della Cahya Kamila. (2015). Determinan tingkat literasi keuangan pelaku UMKM perempuan di Kabupaten Mempawah Kalimantan Barat.

Hilgert,Marianne A., Jeanne M.Hogarth dan Sondra Baverly. (2003). Household Financial Management : The Connection between Knowledge and Behavior.Federal Reserve Bulletin,89(7):309-322. 
Ida dan Chintia Yohana Dwinta. (2010). Pengaruh locus of control, financial knowledge,danincome terhadap financial management behavior. Jurnal Bisnis dan Akuntansi, 12(3): $131-144$.

Japelli, Tulio. (2009). Economic Literacy: An Economic Comparison. Working Paper 289. Centre for studies in Economics and Finance: University of Salerno. www.csef.it/WP/wp238.pdf

diakses pada tanggal 7 Maret 2014.

Krishna, Ayu (2010). Analisis tingkat literasi keuangan di kalangan mahasiswa dan faktor-faktor yang mempengaruhinya (survey pada mahasiswa universitas pendidikan indonesia).

Keown, L. A. (2011). The financial knowledge of Canadians. Component of Statistics Canada Catalogue, 11-008-X, 30-39.

MasterCard. $03 \quad$ Juli 2013. Newzealenders Best at Money Management and Continue to Top http://bit.ly/1cLPC21.

Mandell, L (2008). The financial literacy of young Americam Adult: Result of the national jump\$tart coalition survey of high scholl seniors and college student.

Miranda Gultom,Sambutan Deputi Gubernur Senior Bank Indonesia pada Seminar "Strategi Pengembangan Lembaga Keuangan Syariah di Indonesia" BI, Jakarta 15 September 2005.

Netti tina prilla, Elang ilik M. (2008). Punya bisnis sendiri itu nikmat,
Rahmana, Arief. (2008).Usaha Kecil dan Menengah(UKM), Informasi Terdepan tentang Usaha KecilMenengah, (online), (http://infoukm.wordpress.com, diakses 1 oktober 2011)

Riski Amaliyah Dan Setyo Witiastuti, (2015). Analisis Faktor Yang Mempengaruhi Tingkat Literasi Keuangan Di Kalangan UMKM Kota Tegal.Fakultas ekonomi semarang.

Rita, M.R \&\& Kusumawati,R. (2010). Pengaruh variabel sosio demografi dan karakteristik finansial terhadap sikap, normasubyektif dan control prilaku menggunakan kartu kredit. 109-128.

Sumiyati, (2006). Menuju kecerdasan finansial. Prinsip-prinsip dasar. Alfabeta

Tasya Desiyana. (2015). Analisis Tingkat Literasi Keuangan Pada Pelaku Usaha Mikro Kecil Dan Menengah Di Daerah Istimewa Yogyakarta. Universitas muhammadiyah yogyakarta.

Widayati, I. (2012). Faktor-faktor yang mempengaruhi literasi finansial mahasiswa fakultas ekonomi dan bisnis fakultas brawijaya. Jurnal akuntansi pendidikan 1 (1),89-99. 